\title{
四国中・東部における地震活動
}

$\begin{array}{llllll}\text { 高知大学理学部物理学教室 } & \text { 岡 } & \text { 野 } & \text { 健 之 } & \text { 助 } \\ \text { 高知大学理学部高知地震観測所 } & \text { 木 } & \text { 村 } & \text { 昌 } & \text { 三 } \\ \text { 京都大学理学部徳島地震観測所. 許 } & \text { 斐 } & & \text { 直 }\end{array}$

(昭和 53 年 1 月 12 日受理)

\section{Seismic Activity in the Central and Eastern Part of Shikoku District}

\author{
Kennosuke OKaNO \\ Department of Physics, Faculty of Science, Kochi University
}

\section{Shozo KIMURA}

Kochi Earthquake Observatory, Faculty of Science, Kochi University

\section{Tadashi KoNOMI}

Tokushima Seismological Observatory, Faculty of Science, Kyoto University

(Received January 12, 1978)

The seismic activity in the central and eastern part of Shikoku District is investigated by using data from Kochi and Tokushima Observatory networks. The focal depth distribution shows two distinct groups of earthquakes. The first group of earthquakes with shallower focal depths $(H<20 \mathrm{~km})$ has the pressure axis in E-W direction and the second one with deeper earthquakes $(H>20 \mathrm{~km})$ has the pressure axis in N-S to $\mathrm{N} 10^{\circ} \mathrm{W}-\mathrm{S} 10^{\circ} \mathrm{E}$ direction. Earthquakes determined foci are distributed nearly in the southern part of the Median Tectonic Line and the aseismic activity in the northern part of M. T. L. is noticeable. It seems that aseismic epicentral zones of shallower earthquakes are complemented by seismic activities of deeper ones. It is suggested that the shallower earthquakes are generated by the stress originating from the tectonic activity represented by the deeper ones. The $b$ values of the shallower and the deeper activity regions are estimated at 0.98 and 0.74 , respectively. The difference of these $b$ values may be indicative of the respective characteristics of the regions generating earthquakes. However, we cannot definitely conclude it, because the difference of hypocentral distances of these earthquake groups is closely related to the magnitude estimation. The annual variation of seismic activities is examined from the $b$ values for these two regions. But no remarkable trend is noticed. 


\section{§1. まえがき}

高知大学地震観測所は 1967 年より, 徳島地震観測所は 1975 年より, それぞれ, 観測網を 設けて地震の観測を行つている，その成果は各々の機関から発表されており，これによつて四 国地方の地震活動が次第に明らかになつて来ている，ところで，地震の震源を決定する場合， 観測網から外れる地震はその深さの精度が急激に悪くなるので，各観測網周辺のサイスミシテ ィーについては誤差が大きくなるのが常である，そこで，高知，徳島両観測所はその境界地域 の地震について，それをとり囲む両観測所のデータを用いて震源を決定し，四国の中・東部に おけるより精度のよい震源分布図をつくつた。 さて，四国地域はフィリピン海プレートの沈 み込みがあるといわれ，それと関連していると考兄られる大地震が南海トラフ沿いに起つてい る。をた，内陸部には地殼内地震とマントル内地震が明瞭に区別されて起つており，このマン トル内地震もまたプレートの沈み込みと関係があるといわれている。そこで高知地震観測所の 10 年間の観測結果を用いて，これらのサイスミシティーの性質の違いや，その時間的变化を 調べた。

\section{§2. 観測および震源の計算}

観測点の位置は Fig. 1 に示してある. 観測器械については, 沢村他 (1968), 許斐 (1976) を参照されたい。な㫟高知観測所では 1972 年 4 月より衛星観測点を 2 ケ所増設し現在 5 点で ある.

震源を決めた地震は，いずれかの観測点で， $\mathrm{P} \sim \mathrm{S}$ 時間が 10 秒以下であつて， 4 点以上で 初動が比較的明膫に読める地震を選んだ。地殼構造は Fig. 3 に示してあるように，水平 4 層 構造を仮定した。震源の計算は震央距離と震源の深さをパラメータとする平均速度（震源距離 ／伝播時間）の近似式をつくつて执き，最小自乗法にかける場合，この式から平均速度を出し て，伝播時間の $\delta t_{i}(O-C)$ を求める，といら簡便法を用いた。 この計算法は以前から行って 特り，深い地震に対しては収斂がよいが，浅い地震，特に高知の観測網の北側，特よび東側の 浅い地震に対してはらまく求まらない場合が多い。しかし，今度の両観測所のデータのつき合 わせによつて，高知，徳島間の地震の震源がよく求まり，大へん効果があつた。 しかし，高知 の観測網の北側の三波川変成帯内で起る浅い地震はやはり求まりにくいこれは，木村の (1977) 得た地殼構造から分るように， $5.5 \mathrm{~km} / \mathrm{sec}$ 層と $6.0 \mathrm{~km} / \mathrm{sec}$ 層はほぼ北上りの傾斜 をして拈り，三波川帯では $5.5 \mathrm{~km} / \mathrm{sec}$ 層が大へんうすくなつているためかも知れない，一方， PS-P 法で求める発震時にも間題があると思われるので, これらを考慮して発震時を多少操作 し，震源を計算した。 


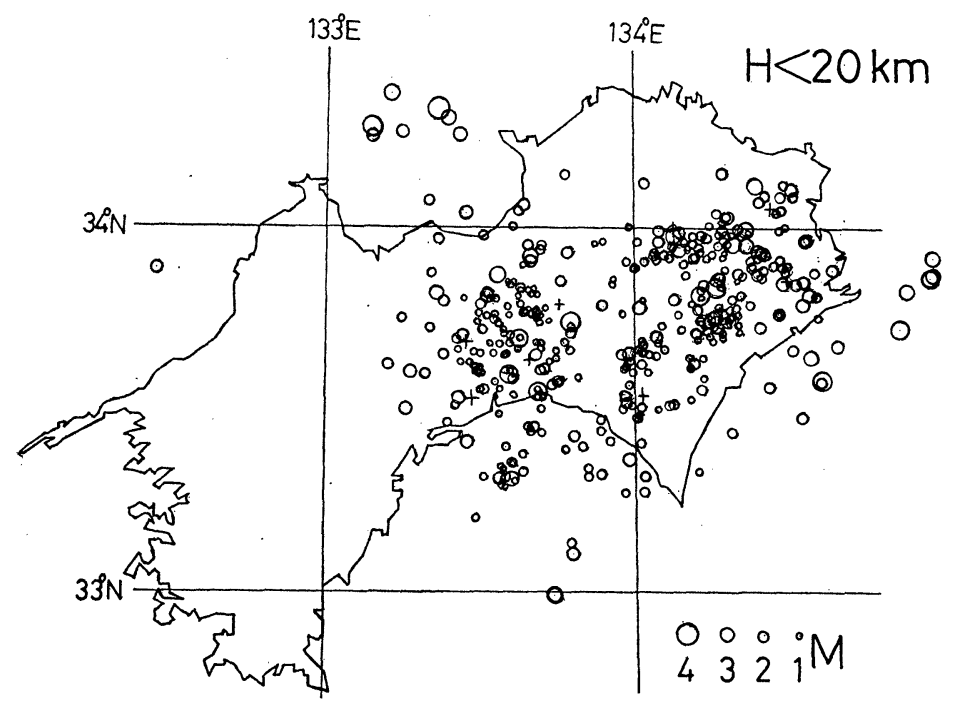

Fig. 1. Epicenter distribution of shallower earthquakes $(H<20 \mathrm{~km})$ in 1975 and 1976.

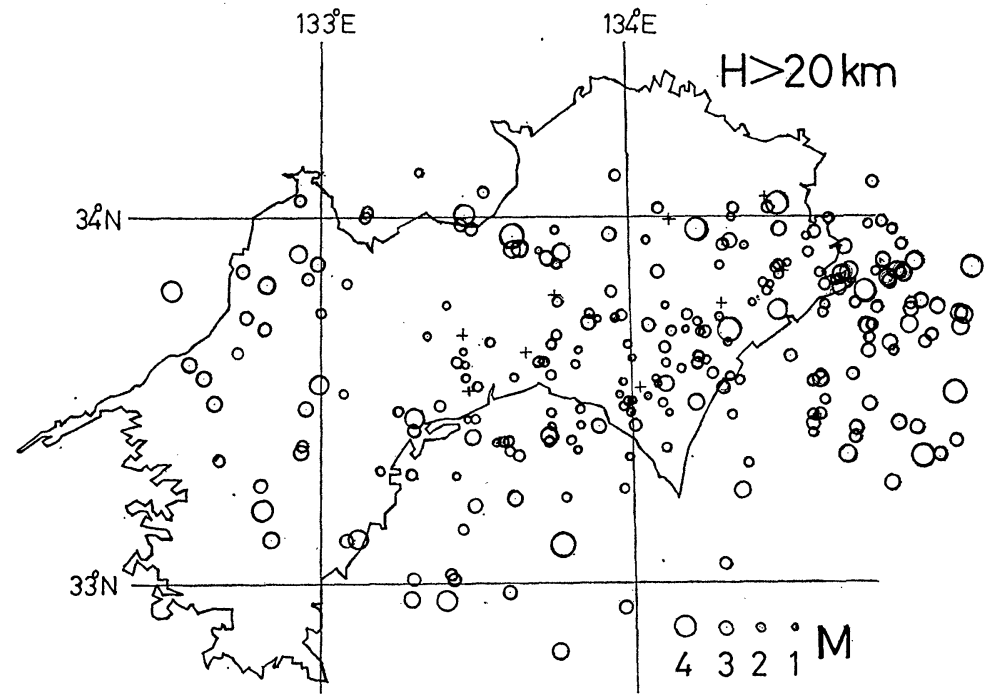

Fig. 2. Epicenter distribution of deeper earthquakes $(H>20 \mathrm{~km})$ in 1975 and 1976 .

\section{§3. 震源分布と $\mathbf{P}$ 波初動の押し引き分布}

震央分布を，震源の深さが $20 \mathrm{~km}$ より浅い地震と，深い地震とに分けて，それぞれ，Fig.

1，Fig. 2 飞示す．期間は 1975，1976 年の 2 年間である。.また，南北㧍よび東西の鉛直断面 上の震源分布は，岡野他 (1977) を参照されたい，これらの図から気がつくことは，まず両方 の地震とも中央構造線より北側でサイスミシティが極端て低いことである。これは紀伊半島で 
も $50 \mathrm{~km}$ より浅い地震について見られることで [例えば，和歌山微小地震観測所 (1976) ] , この程度の深さまでは中央構造線がサイスミシティに何らかの影響を与えているものと思われ る.これ以上の深さの地震は紀伊半島と異り，中央構造線の北側には発生していないものと思 われる．深い方の地震は四国全域に発生している，従来より，気象庁による震源分布から四国 の西部地域ではサイスミシティが極端に低いと考えられているが，深い方の地震についてはあ まり変わらない，一方浅い地震の方は，四国の西部地域でサイスミシティが大へん低く，東部 地域で高い。また高知と徳島の境界地域でやや低くなつていることに気付く．

ここで興味深いことは, 高知, 徳島両観測網の中に深い地震の低活動域があるが, この地域 を埋めるような形で浅い地震の高活動域が存在しているように見えることである. 前述の両観 測網の境界地域も又その傾向が見られ，深い地震のサイスミシティが高い。このように深い地 震と浅い地震が異つた地域に相補的に起ることは和歌山括よび中部地方でも見られる.

つぎに Fig. 3 から浅い地震と深い地震とが，深さの点から見てかなりはつきりと分れて発生 していることが見られる，この図は，プレートのもぐり込みの方向が南海トラフと直角である といら考劣と，木村の層構造の傾斜方向が御荷鉾構造線にほぼ垂直であるということを考えて， $\mathrm{N} 22^{\circ} \mathrm{W}-\mathrm{S} 68^{\circ} \mathrm{E}$ 方向の鉛直断面上への震源の投影を示したものである. 浅い地震は北上りに, 深い地震は北下りに分布しているが，この深い地震の北下りの分布はフィリピン海プレートの 沈み込みの考光の裏付けとなつている，しかし，必ずしも四国全域で同じパターンを示してい る訳でもないようなので，いくつかの地域に分けて見た．Fig. 4 に示すよらに， $30 \mathrm{~km}$ の幅 を持つた， $\mathrm{A} \sim \mathrm{F}$ の 6 つ地域に分け，それぞれの地域についての断面分布図を Fig. 5 に示 于.

これらの図を見ると地域によつてかなり様子が違つている. 高知周辺の B 地域では浅い地

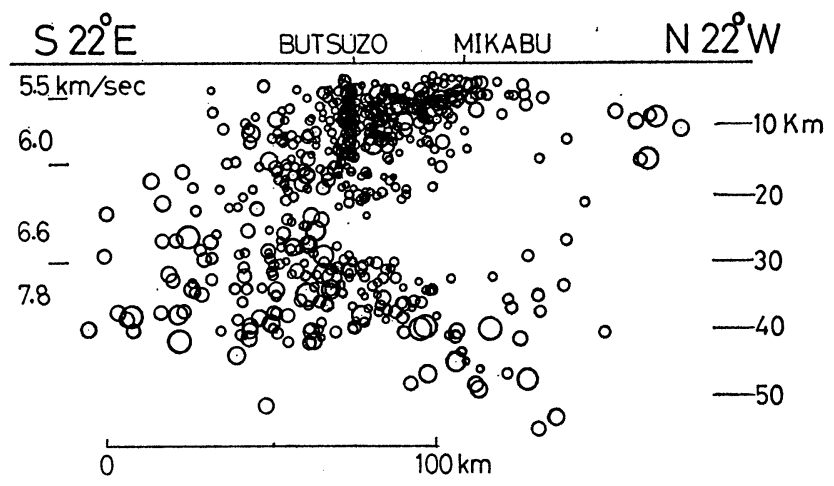

Fig. 3. Focal depth distribution of earthquakes in a vertical section $\left(\mathrm{N} 22^{\circ} \mathrm{W}-\mathrm{S} 22^{\circ} \mathrm{E}\right)$ with the assumed crustal structure. 
震の下限と深い地震の上限が極めて接 近しているが, 徳島のD地域でははつ きりと分れている．またB地域での浅 い地震の北上り, 深い地震の北下り分 布は，D地域では明瞭でなく， $\mathrm{E}$ 地域 になると殆んど傾斜はなくなり水平の 震源分布になる，このように四国とい らあまり広いとはい党ない地域にお いても様子は大へん複雑である.

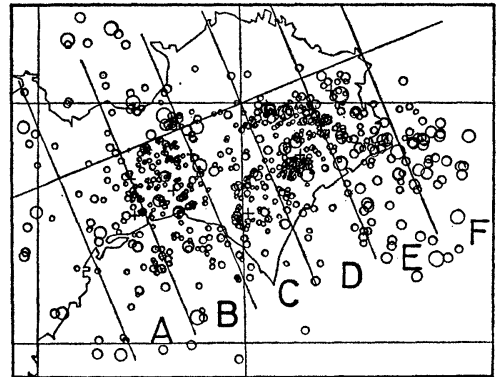

Fig. 4. Chart showing six regions with $30 \mathrm{~km}$ widths. Focal depth distributions in these regions are shown in Fig. 5.

つぎに，震源分布と地殼構造との関連について考える. 地殼内地震が $6.0 \mathrm{~km} / \mathrm{sec}$ 層内に起 ることが多いということは，微小地震の観測が始つてから全国的に気付かれていることである が，これを四国の地震分布について見ると，浅い地震が地殼内地震といらことになる．これは 木村の得た構造とよく合つていて，地震発生域の上面は北上りに傾斜しており，三波川变成帯

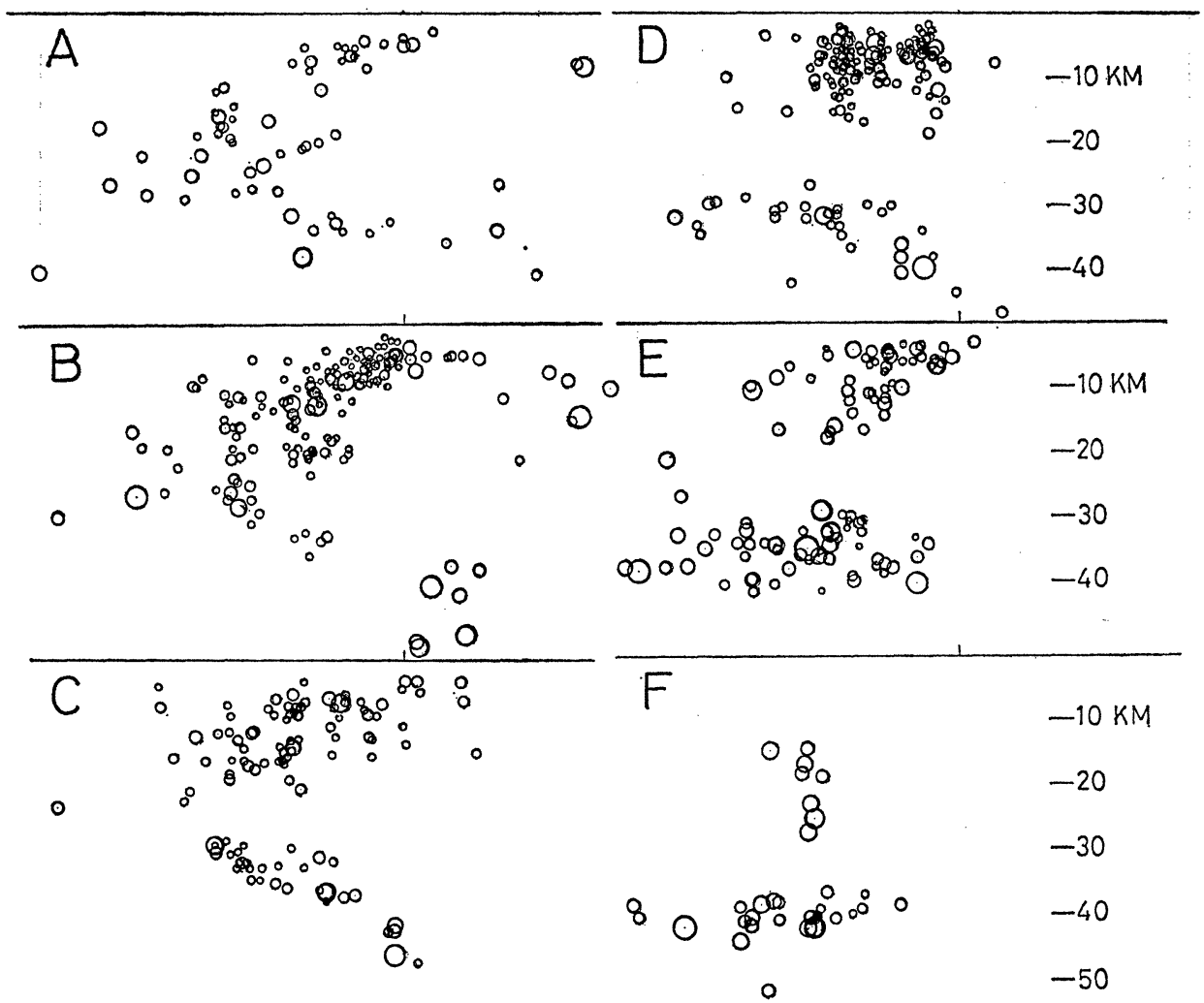

Fig. 5. Focal depth distributions of earthquakes for the six regions shown in Fig. 4. 


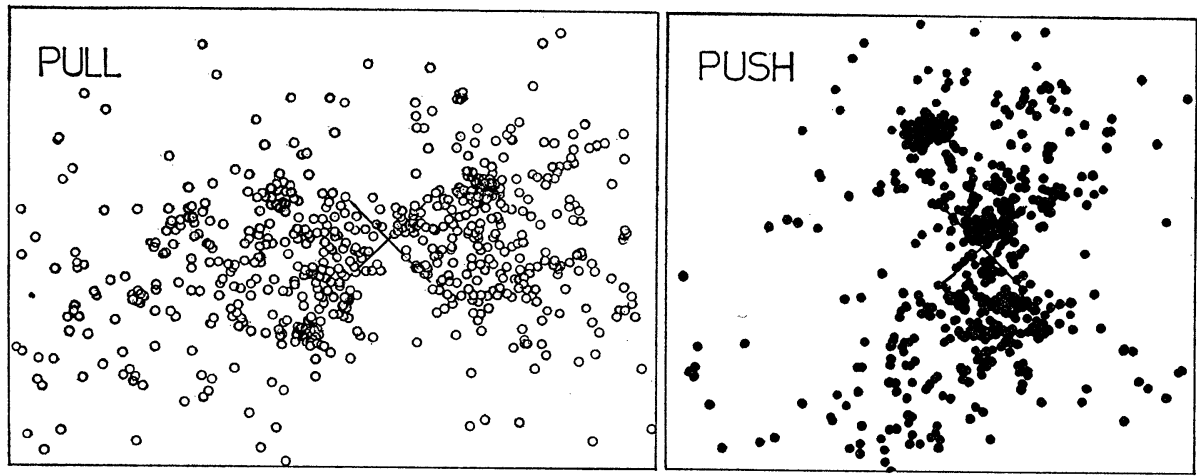

Fig. 6. Distributions of dilatational and compressional motions of the $\mathrm{P}$ initial wave for earthquakes with shallower depths than $15 \mathrm{~km}$.

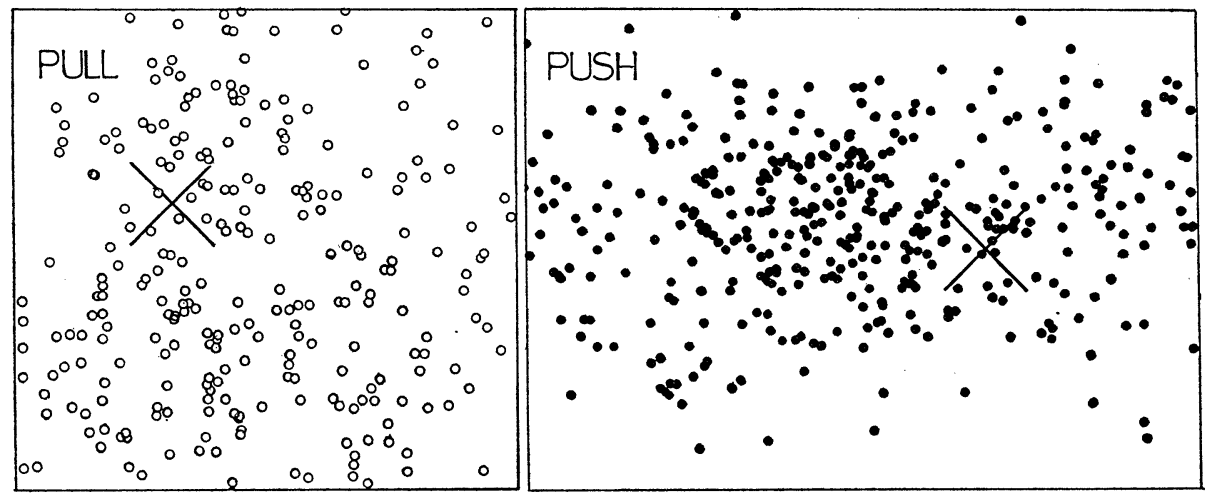

Fig. 7. Distributions of dilatational and compressional motions of the $\mathrm{P}$ initial wave for earthquakes with deeper depths than $25 \mathrm{~km}$.

ではこの上面が浅くこの地域の浅い震源分布と合つている. ただ木村の構 造は, $6.0 \mathrm{~km} / \mathrm{sec}$ 層の下面が分らないので，この下面が震源分布と合つているかどうか不明である。では，深い 方の地震は何処に当たるのであろうか．地凯内なのかマントル内なのか大へん興味のあること である，地殼内とすると，地殼の厚さが $50 \mathrm{~km}$ にまで達していると考えなくてはならず，ま たマントルとすると，B 地域で見られるように地殸の厚さは僅か $20 \mathrm{~km}$ 程度でしかないこと になる、また，プレート内であると考劣るならば，ホモ面の位置は何処なのか．これらについ ては今後精密な地震波速度の測定によつて解決されねばならない。

つぎに，これらの深さの違らそれぞれの地震はその起震主圧力の方向が互いに直角であると いうことは周知のことであるが，これを示すために，それぞれの地震について重ね合わせの押 し引きの分布を Fig. 6, Fig. 7 に示す. 震源の決定精度を考光て, 浅い方の地震は $15 \mathrm{~km}$ よ り浅いもの，深い方の地震は $25 \mathrm{~km}$ より深いものをとつた。これらの図を見ると，浅い方の 
地震は押しと引きがよく分れているが， 深い方の地震はあまりよく分れず節線 をはつきりと引くことができない.し かし大体の見当をつけて見ると, 主圧 力の水平成分の方向はほぼ南北か, や や反時計まわりに傾く程度である。こ れは個々の地震についての押し引きの 分布である Fig. 8 に見られるように， 深い方の地震は注㳯南北方向の主圧力 を持ち, dip の成分はあまり見られな いことからも誤ではなからう.この深 い方の地震については, フィリピン海 プレートのもぐり込みの方向に dip を 持つといわれているので, さらに個々 の地震について詳細に検討して行き度 い, 浅い方の地震については, 添東 西主圧力と考光て異論はなからう。气 うすると, これらの方向は, フィリピ ン海プレートが沈み达むと考光られて いる南海トラフや地殼層の傾斜方向と 直角をなす御荷鉾構造線の方向とかな り違つているよう思われる。すなわ ち地震を起す力の方向がフィリピン海 プレートのもぐり达みの方向と合わな いことになる。これをどのように考兄 たらよいのであろらか.

ところで, 核涪 $20 \mathrm{~km}$ の深さを境として, 起震力の方向が直角になつているという事実に ついては, 浅い部分の東西方向の起震力ははるか東の太平洋プレートによるもの, 深い部分に 働く南北方向の起震力はフィリピン海プレートによるもの，と 2 つのォを考えるのが常である が, これは考觉難く, やはりどちらか一方の方向の力が加わつて, 他の方向の力は二次的なる のとする方が考觉易いのではなかららか，そうであるとすると，深い方の部分に働く南北方向 
の力を一次的なものであると考光, 自由表面に近い浅い部分に動く力を二次的なものとする方 が考え易いように思われる. 浅い地震と深い地震の震央分布の相補的性質はこのことと関連が あるようにも考えられる.な和この点については，金森（1971）がすでに同じような考えを出 しており, また, 塩野 (1977) は parallel extension の考方方から深い方の地震の起震力を説 明している。

\section{§4. 地震活動度の変化}

高知地震観測所の 10 年間のデータからサイスミシティの変化を調ベた. 観測点は最初の 5 年間は 3 点で, 途中 2 点増設して 5 点になつのたで, 多少データの均質性を失うかも知れない がここでは考觉に入れていない.

Fig. 9 は 10 年間に震源を決めた全地震についてマグニチュードの頻度分布を示したもの である．点がかなりばらついているが，直線部分についてbの值を計算すると，浅い地震につ いては 0.98 , 深い地震については 0.74 が得られた.この深い地震の 0.74 という值は一般的 にいつてやや小さく, 浅い地震の $b$ 值との差は有意であるかも知れない。そうであれば, これ はそれぞれの地震の起る地域の物理的性質の差を示しているのかも知れない，しかし，両方の 震源分布を考えると，観測点からの距離が大へん異つている．深さの点で違つていることはい うまでもないが, 震央の点でも深い方の地震は四国全域にわたつている一方, 浅い方の地震は

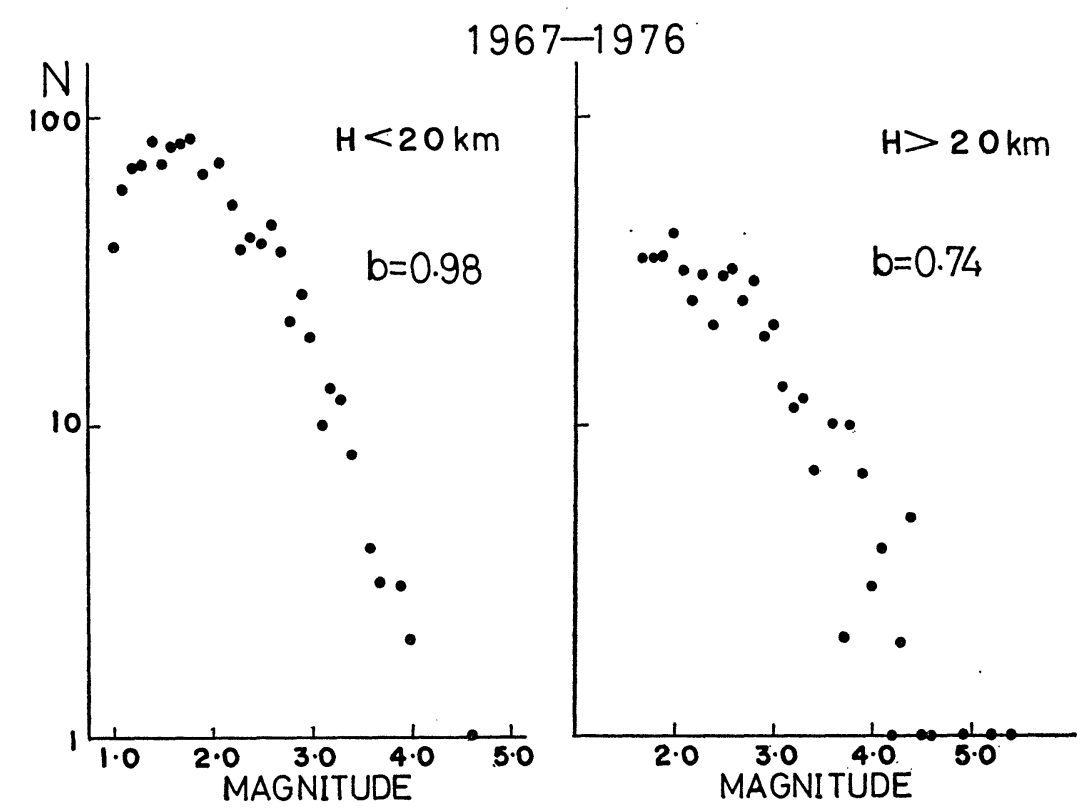

Fig. 9. Frequency distributions of magnitudes of the shallower and the deeper earthquakes for ten years from 1967 to 1976. 

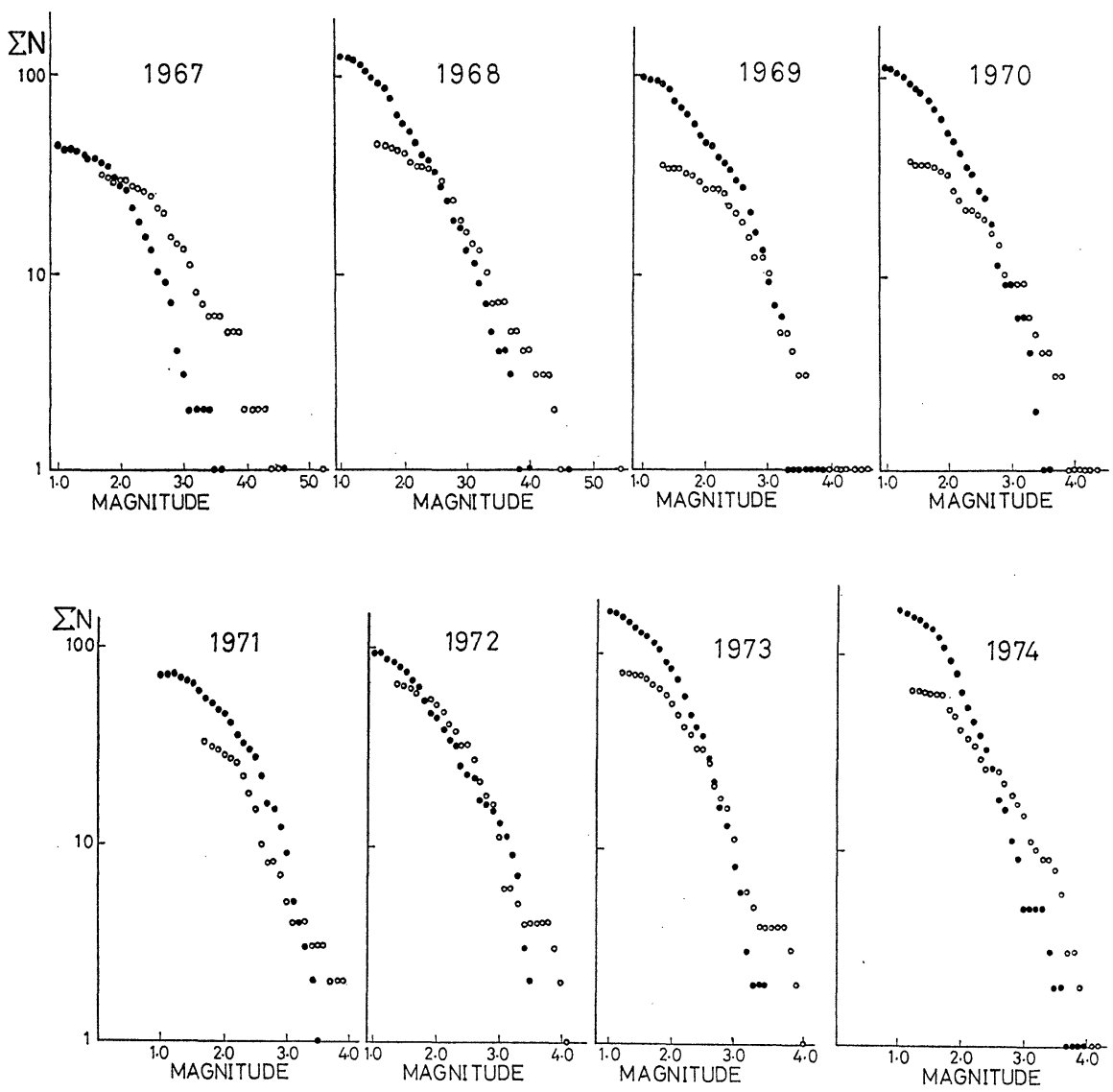

全体的に震央距離が小さい。このこと がどの程度 $b$ 值に影響するものか検討 した訳ではないが, 地震波の減衰とい らかなり複雑な問題がからんでくるこ となので結論を出すことは早急であろ 亏.

次に, 10 年間のサイスミシティの 変化を調べるために，各年毎の頻度分 布をFig. 10 に示す. 四国は全般的に サイスミシティが低く，1年間のデー

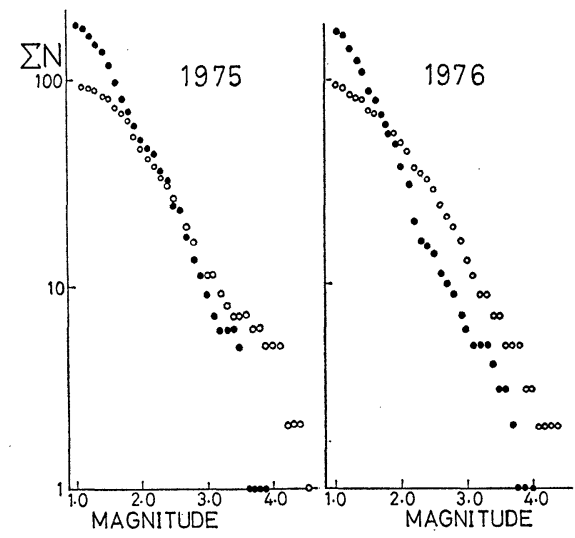

Fig. 10. Cumulative frequency distributions of magnitudes of the shallower (solid circles) and the deeper (open circles) earthquakes for every years from 1967 to 1976. 
タだけではなめらかな曲線が得られないので，積算頻度分布を用いた．図から見られるように， 年によつて多少の相違はあるが特に著しい变化は見られない。市川 (1965) は, 南海道地震前 後で起震力の方が南北から東西に变つたのではないかという結果を得ているので，我々は特 に浅い地震と深い地震との相対的なサイスミシティの変化を見出すことを期待したのであるが， よく分らなかつた。 ただ，1975，1976 年に深い地震の $b$ 值が大きくなつたように見える.

以上のように意味のありそうな変化が見られなかつたのは，この地域のサイスミシティが大 地震の発生に無関係なのか，10 年間といら期間が短かいために気付かないのか，または大地 震の発生直前にならないと変化があらわれないのかは，現在のデータからは明らかでない。

\section{$\S 5$. あとがき}

高知，徳島両観測所の共同作業によつて，四国中・東部についての精度のよいサイスミシテ ィが得られた。これによつて幾つかの問題が考えられるのであるが, 特に震源分布と地殼構造 との関係を明らかにすることが重要である．浅い地殼内地震については或程度の理解が得られ たが，深い方の地震については未知の点が多い，地震の起つている部分が地殸内なのかマント ル内なのかといらことも分らない，また，浅い地震と深い地震の分布が上下に分れていて，そ れらの起震力の方が直交していることは，単純に二方向の力を考えるだけでは説明できない のではなかららか.さらに, 南海トラフに沿つて起る大地震とこの地域に起つている微小地震 がどのような関連を持つているのか，そしてフィリピン海プレートの位置は何処であるのか， など問題は多い。今後精密な観測を行って明らかにして行き度い。

震源の計算, 図の作成等に当つて, 高知大学計算センターの御厄介になりました。厚く御礼 申し上げます。

\section{文献}

IcHIKaWA, M, 1965, The Mechanism of Earthquakes Occurring in Central and Southwest Japan and Some Related Problems, Pap. Meteorol. Geophys., 16, 104-156.

Kanamori, H. and K. Tsumura, 1971, Spatial Distribution of Earthquakes in the Kii Peninsula, Japan, South of the Median Tectonic Line, Tectonophysics, 12, 327-342.

木村昌三，1977，四国地方の地殼構造(II)，昭和 52 年度地震学会春季大会講演予稿集， 17. 許斐 直, 1976, 四国東部の地震活動(II)，昭和 51 年度地震学会春季大会講演予稿集， 15 . 岡野健之助・木村昌三・許斐 直, 1977, 四国地方の地震活動, 地震予知連絡会会報, 18, 117-119. 沢村武雄・木村昌三, 1968 , 四国中央部における微小地震活動(I), 高知大学学術研究報告, 17 , 自然科学, $4,1-9$.

Shiono, K, 1977, Focal Mechanism of Major Earthquakes in Southwest Japan and Their Tectonic Significance, J. Phys. Earth, 25, 1-26.

和歌山微小地震観測所, 1976, 紀伊半島拈よび周辺各地の地震活動の比較, 和歌山微小地震観測所季報, $10,37$. 